\title{
Analysis of the Potential for Sustainable Development Based Food Products to Support Tourism Fisheries and Economic Community in the Province of Bali
}

\author{
Muhammad Marzuki \\ Lecturer Mataram of University, Indonesia \\ Sunarpi \\ Lecturer Mataram of University, Indonesia
}

Amirudin

Lecturer Mataram of University, Indonesia

Muhammad Ridwan

Student Mataram of University, Indonesia

Received: November 10, 2015 Accepted: April 13, 2017

doi:10.5296/emsd.v6i2.8554 URL: https://doi.org/10.5296/emsd.v6i2.8554

\begin{abstract}
This study aims to understand index value and the status of sustainability the potency advancement food products based on fisheries to support the program tourism the action plan for accelerated and expansion of economic development in the Bali Province. Analysis index and sustainability management status food products based on fisheries (existing condition) every dimension do with this multidimensional approach scaling (MDS) to technique ordinary modified from the program raffish. The results of the analysis multi-deme si about the status of sustainability the development of food products based on fisheries Earth Easth Nusa province showing that the index continued to the development of food products based on fisheries 51,70 status of the show "Sustainable Enough". The development of food products based on fisheries to ensure that tourism and economic community in the Bali necessary policy interventions with the order priority in the economic dimension index value
\end{abstract}


42.29, technology index value 50.09, and social dimension index value 58,05. Policy interventions can be implemented towards indicator own value leverage high to can increase index value and status sustainability on each dimension.

Keywords: Analysis Sustainability, Food Products, Fisheries, Tourism, Economic Community

\section{Introduction}

The government is currently implementing the Master Plan for the Acceleration and expansion of Indonesia Economic Development (Penprinas-MP3EI) with the aim to accelerate and strengthen economic development in accordance with the advantages and the strategic potential of their respective territories.

In the MP3EI, the island Bali -Nusa Southeastern included in corridor V themed "Gate of Tourism and National Food Support" the main economic activities are: tourism, farming, and fisheries. Tourism development always ebbs and flows in line with global influence. The economic downturn as a result of the heavy burden of foreign debt, the strength of the country as a tourism activity is very promising to move the community's economy. The potential of fisheries in Bali province has not been used optimally. Utilization of fishery preferred to produce quality food products and nutritional value to support tourism and boost the economy of the people.

The Fisheries sector is seeded in the province of Bali province. Hence, this study was conducted to obtain information about the current state of (existing condition) the development of food products based fisheries to support tourism and community economy improvement in the province of Bali province.

\section{Method}

\subsection{Place and Time of Study}

This study was done in Bali province. The research was conducted from March to November 2014.

\subsection{Kind and Data Source}

The required data are primary and secondary data associated with the attributes based food product development dimension of fisheries sustainability: the dimensions of raw materials, economic, social, technological and institutional.

\subsection{Data Collection Method}

The primary data was obtained through field observation, interviews with processing businessman fisheries products. Discussion deep done by experts includes academics, government officials, entrepreneurs product processing, entrepreneurs marketing food products. The primary data obtained by direct observation in the study site and of the respondents and experts were elected, while secondary data obtained from literature sources and documents some of the institutions associated with the research. 


\subsection{Data Analysis}

An analysis of the sustainability of the development of food products based fisheries to supporting the tourism and economic community method done with the approach of multidimensional scaling (MDS) with Rap Insults technique food products that has been modified from program Rapfish (Kavanagh, 2001; and Pitcher Preikshot, 2001 Fauzi and Anna, 2002). MDS method is a statistic technique computer-based using SPSS software. It has been developed from Rapfish G77 Alscal (VBA and Excel) program to Simple Rap Insults Mariculture Alglib (.net Windows Application) program being easier in operating and doing the transformation on every dimension as well as multidimensional of mariculture management sustainability in Saleh Bay. Determination of each attribute in the dimension of the ecological, economic, social-cultural, technological and infrastructure as well as legal and institutional referred to an indicator of Rapfish (Kavanagh, 2001; Tesfamichael and Pitcher, 2006; Charles, 2000, and Nikijuluw, 2002) with some modifications.

The attribute of each dimension and criteria of good or bad followed the concept of Rapfish (Kavanagh, 2001) and judgment experts/knowledge stakeholders. Every attribute was estimated its score namely; the score of 3, 0 and 0-3 for good, bad and between good and bad conditions, respectively. The score is the value of modus analyzed to determine dots reflecting the relative sustainability position on the good and bad dot through MDS statistic ordination technique. Estimation score of every dimensions was expressed from (bad scale) $0 \%$ to (good scale) $100 \%$, and into four categories namely: 0-25\% (bad or unsustainable), 25,01-50\% (less sustainable), 50,01-75\% (fairly sustainable) and 75,01-100\% (highly sustainable).

Ordination technique or distance determination in the MDS based on Euclidian Distances in which according to n-dimension it can be written as followed:

$$
d=\sqrt{\left(\left|\mathrm{x}_{1}-\mathrm{x}_{2}\right|^{2}+\left|\mathrm{y}_{1}-\mathrm{y}_{2}\right|^{2}+\left|\mathrm{z}_{1}-\mathrm{z}_{2}\right|^{2}+\ldots \ldots\right)}
$$

Later, configuration or ordination of an object or a point in the MDS was approximated by regressing the distance of Euclidian (dij) from point $\mathrm{i}$ to point $\mathrm{j}$ with the origin point $(\sigma \mathrm{ij})$ as the following equation:

$$
d_{i j}=\alpha+\beta \delta_{i j}+\varepsilon
$$

The technique used to regress the equation above was Algoritma ALSCAL (Alder et al., 2000 in Fauzi and Anna, 2005). It was a suitable method for Rapfish and had by almost all of statistic software (SPSS and SAS). The ALSCAL method optimizes square distance (dijk) on quadrate data or origin point (dijk), in which in three dimensions (i, j, k) were well known as S-Stress equation as followed:

$$
s=\sqrt{\frac{1}{m} \sum_{k=1}^{m}\left[\frac{\sum_{i} \sum_{j}\left(d_{i j k}^{2}-o_{i j k}^{2}\right)^{2}}{\sum_{i} \sum_{j} o_{i j k}^{4}}\right]}
$$




\section{Macrothink}

Square distance is the distance of Euclidian with the equation as followed:

$$
d^{2}=\sum_{\alpha=i}^{r} w_{k a}\left(x_{i a}-x_{j a}\right)^{2}
$$

The goodness of fit in MDS is reflected off on S-Stress value counted based on the value of $S$ and R2. The low-stress value shows good fit whilst, the high $S$ value exhibits bad fit. In Rapfish, the good model is shown by the stress value $(S)<0.25$ whilst, the good R2value is $S$ value approaching 1. Evaluation of random error influence (Error) used Monte Carlo analysis to determine: (a) the influence of attribute score making error, (b) variation influence of score giving, (c) stability of repetitive MDS analysis, (d) missing data, and (e) stress value can be accepted if it has $\mathrm{S}<20 \%$ (Pitcher and Preikshot, 2001).

\section{Result and Discussions}

\subsection{Index and Sustainability Status of Material Dimension}

The results of the analysis of Rap Insults Food Products fishery-based food product development to support tourism and economy of the six attributes of an effect on the dimensions of the raw material was obtained that the value of sustainability index on the dimensions of the raw material of "70.97". The index value is between 50.00 to 74.9 means "Sustainable Enough". The index value less sustainable approach status and if the conditions are not made efforts to an improvement of social conditions or be left as it is today, it will affect other dimensions of sustainability so that the fishery-based food product development for tourism and economic support fishing communities tend to be unsustainable.

\subsection{Index and Sustainability Status of Economic Dimension}

The results of the analysis of Rap Insults Food Products fishery-based food product development to support tourism and economy of the eight attributes affect the economic dimension, shows that the value of sustainability index on the economic dimension of "42.29". The index value is between 25.00 to 49.9 means "Sustainable Less". If the conditions of the economic dimension are left as it is today, it will affect other dimensions of sustainability so that the fishery-based food product development for tourism and economic support fishing communities tend to be unsustainable.

\subsection{Index and Sustainability Status of Social Dimension}

The results of the analysis of Rap Insults Food Products fishery-based food product development to support tourism and economy of the six attributes of an effect on the social dimensions, obtained that the value of sustainability index on the social dimensions of "58,05". The index value is between 50.00 to 74.9 means "Sustainable Enough". The index value less sustainable approach status and if the conditions are not made efforts to an improvement of social conditions or be left as it is today, it will affect other dimensions of sustainability so that the fishery-based food product development for tourism and economic support fishing communities tend to be unsustainable. 


\section{Macrothink}

Environmental Management and Sustainable Development

ISSN 2164-7682

2017, Vol. 6, No. 2

\subsection{Index and Sustainability Status of Technological Dimension}

The results of the analysis of Rap Insults Food Products fishery-based food product development to support tourism and economy of the six attributes affect the technological dimension, shows that the value of sustainability index on the institutional dimension of "50.09". The index value is between 50.09 to 74.9 means "Sustainable Enough". However, the index value is close to the value less sustainable. If there are no efforts to increase technological innovation, then the value of the index tend to be unsustainable and will affect the sustainability of the other dimension so that the fishery-based food product development to support tourism and the local economy becomes unsustainable fisheries.

\subsection{Index and Sustainability Status of Institutional Dimension}

The results of the analysis of Rap Insults Food Products fishery-based food product development to support tourism and economy of the six attributes affect the technological dimension, shows that the value of sustainability index on the institutional dimension of "50.09". The index value is between 50.00 to 74.9 means "Very Sustainable". Value of the index on the institutional dimension supports sustainability, but if it is left as it is today, it will affect the sustainability of the other dimension so that the fishery-based food product development to support tourism and the local economy are likely unsustainable fisheries.

\subsection{Leverage Factor}

The results of the analysis of the leverage on Rap analysis techniques Insults Food Products fishery-based food product development to support tourism and economic community in Bali Province. Changes to easily leverage these factors will affect the value of the index and sustainability status. Leverage factors in detail each of the dimensions of sustainability are presented in Table 1.

Table 1. Factors Levers Fifth Dimension Sustainability-Based Food Product Development of Fisheries to Support Tourism and Community Economy in Bali Province

\begin{tabular}{|c|l|c|}
\hline No & \multicolumn{1}{|c|}{ Factor Levers } & RMS Value \\
\hline \multicolumn{2}{|c|}{ Dimensions Raw Materials } \\
\hline 1 & Environmental Management Food Product Development & 8,51 \\
\hline 2 & Development of Food Product Production & 12,56 \\
\hline 3 & Season Effect Against Food Product Availability & 8,26 \\
\hline \multicolumn{2}{|c|}{ Social dimension } & 5,91 \\
\hline 1 & Level Promotion of Food Products & 4,82 \\
\hline 2 & Value Added Food Products & 1,98 \\
\hline \multicolumn{2}{|c|}{ Technology Dimensions } & 1,96 \\
\hline 1 & Level Formal Education Business Actor & 1,09 \\
\hline 2 & Cooperation Business Actor & 1,25 \\
\hline 3 & Consumer Access To Food Products \\
\hline \multicolumn{2}{|c|}{} \\
\hline 1 & Support Infrastructure Processing and Marketing \\
\hline
\end{tabular}




\begin{tabular}{|c|l|c|}
\hline 2 & Food Product Diversification & 2,13 \\
\hline 3 & Quality Packaging & 1,53 \\
\hline \multicolumn{2}{|c|}{ Institutional Dimensions } \\
\hline 1 & Institutional Marketing & 0,17 \\
\hline 2 & Institutional Business Training & 0,32 \\
\hline 3 & Institutional Capital & 2,76 \\
\hline
\end{tabular}

Source: Analysis Result (2014)

\subsection{Index and Multidimensional Sustainability Status}

Rap analysis results Insus Food Products fishery-based food product development to support tourism and economic community in Bali Province is multidimensional in the five dimensions of sustainability. Results of weighting the five dimensions of sustainability, the obtained values of sustainability multidimensional index of 51.70. The value of the index lies between 50.00 to 74.9 means "Sustainable Enough". In tabulating the value of the multidimensional index fishery-based food product development to support tourism and economic community in Bali Province based test pair wise comparison are presented in Table 1 .

Table 2. The value of sustainability index multidimensional fishery-based food product development to support tourism and economic community in Bali Province

\begin{tabular}{|l|c|c|c|}
\hline \multicolumn{1}{|c|}{ Dimensions Value } & $\begin{array}{c}\text { Weights Weighted } \\
\text { Value (\%) }\end{array}$ & $\begin{array}{c}\text { Sustainability Index } \\
\text { Value }\end{array}$ & $\begin{array}{c}\text { Weighting } \\
\text { ResultsResource }\end{array}$ \\
\hline Recources & 0.24 & 82,50 & 17,03 \\
\hline Economic & 0.22 & 42,29 & 7,54 \\
\hline Social & 0.18 & 58,05 & 10,45 \\
\hline Technology & 0.21 & 50,09 & 10,52 \\
\hline Institutional & 0.15 & 41,03 & 6,15 \\
\hline Multidimensional index value & 51,70 \\
\hline
\end{tabular}

Source: (Result Analysis, 2014).

\subsection{Monte Carlo Analysis}

Monte Carlo analysis shows that the value of sustainability index food product development based fishery to support tourism and economic community in Balicprovince at a level of 95\% showed that the results of analysis Rap Insus Food Products between analysis MDS with Monte Carlo did not experience any significant difference (Table 2). The small differences in the results of two analyzes showed that; (1) error in making a score in the attributes of a relatively small, (2) a variety of scoring due to differences in opinion are relatively small, (3) the analysis process carried out repeatedly relatively stable, (4) errors in data entry and data loss can be avoided. 


\section{Mll Macrothink}

Environmental Management and Sustainable Development

ISSN 2164-7682

2017, Vol. 6, No. 2

Table 3. Results of Monte Carlo analysis to value Rap Insus Food Products at 95\% confidence interval fishery-based food product development to support tourism and the local economy in the province of Bali

\begin{tabular}{|c|c|c|c|}
\hline Dimensions & $\begin{array}{c}\text { Value } \\
\text { MDS Analysis }\end{array}$ & $\begin{array}{c}\text { Index Value } \\
\text { Monte Carlo Analysis }\end{array}$ & $\begin{array}{c}\text { Index Difference Value Index } \\
\text { (MDS-MC) }\end{array}$ \\
\hline Recources & 70,97 & 70,71 & 0,26 \\
\hline Economics & 34,28 & 33,92 & 0,36 \\
\hline Social & 58,05 & 57,79 & 0,26 \\
\hline Technology & 50,09 & 49,54 & 0,55 \\
\hline Institutional & 41,03 & 40,93 & 0,10 \\
\hline
\end{tabular}

Results Insus Food Products Rap analysis indicates that all attributes assessed against sustainability status of fisheries based food product development to support tourism and economic community in Bali province are quite accurate and reliable. This is indicated by the value of stress under the 0.25 figure and the coefficient of determination (R2) of 0.94. This is in accordance with the opinion of Fauzi and Anna (2005) which states that the results of the analysis is sufficient if the stress value less than $0.25(25 \%)$ and the coefficient of determination close to the value of 1.0. In detail, the stress and the coefficient value determines census Food Products Rap analysis with Monte Carlo analysis of fishery-based food product development to support tourism and the local economy in the province of Bali are presented in Table 3.

Tabel 4. Stress Values and Coefficient of Determination Analysis Insus Seaweed and Rap-Rap-Insus

\begin{tabular}{|l|l|l|l|l|l|l|l|}
\hline \multirow{2}{*}{ Dimensions } & \multirow{2}{*}{ Sustainability Index Value } & \multicolumn{2}{l|}{ Stress } & \multicolumn{2}{l|}{$\mathbf{R}^{\mathbf{2}}$} & \multicolumn{2}{l|}{ Iteration } \\
\cline { 5 - 9 } & & & & & & & \\
\hline Resources & 70,97 & 0,13 & 0,13 & 0,94 & 0,94 & 2 & 2 \\
\hline Economics & 34,28 & 0,13 & 0,13 & 0,95 & 0,95 & 2 & 2 \\
\hline Social & 58,05 & 0,13 & 0,13 & 0,95 & 0,94 & 2 & 2 \\
\hline Institutional & 50,09 & 0,14 & 0,13 & 0,95 & 0,95 & 2 & 2 \\
\hline Technology & 41,03 & 0,14 & 0,14 & 0,94 & 0,95 & 2 & 2 \\
\hline
\end{tabular}

Source: Analysis Result (2013)

\section{Conclusions and Recommendations}

\subsection{Conclusion}

a. Status of food product development in Bali based fishery indicates the status of ongoing enough.

b. Food product development to support tourism and the local economy in Bali-based 
fisheries policy interventions need to be done in order of priority dimensions of economic, technological, and social.

c. Policy interventions to develop a fishery-based food products that can support the development of tourism and improve household incomes made to the sustainability indicators of each dimension so that it will raise the value of the index of sustainability status of fisheries based food product development.

\subsection{Suggestion}

a. Necessary to formulate a strategy to increase the value of the index and sustainability status of each dimension sustainability fishery-based food product development strategy formulation based on the priority order of each dimension of sustainability lowest index value.

b. Implementation of the strategy of increasing the value index and sustainability status of fisheries based food product development to support tourism and the local economy, it is necessary to formulate the Action Plan or Program Indicative short term, medium term and long term together by involving all stakeholders

\section{References}

Alder, J., Pritcher, T. J., Preikshot, D., Kaschner, K., \& Ferriss, B. (2001). How Good is Good?: A Rapid Appraisal Technique for Evaluation of the Sustainability Status of Fisheries of the North Atlantic. Fisheries Centre. The University of British Columbia. Vancouver, Canada.

Charles, A. T. (2000). Sustainability Fishery Systems. Sain Mary's University Halifax, Nova Scotia, Canada. 370 p. Jakarta. https://doi.org/10.1002/9780470698785.ch10

Fauzi, A., \& Anna, Z. (2005). Modeling of Marine and Fisheries Resource for Policy Analysis. Jakarta, Gramedia.

Fauzi, A., \& Anna, S. (2002). Status Evaluation of Fisheries Development Sustainability, RAPFISH Application, Case Study of DKI Jakarta Coastal Waters. Journal of Coastal and Marine, 4(3).

Pitcher, T. J., \& Preikshot, D. B. (2001). Rapfish: A Rapid Appraisal Technique to Evaluate the Sustainability Status of Fisheries. Fisheries Research, 49(3), 255-270.

https://doi.org/10.1016/S0165-7836(00)00205-8

Nikijuluw, V. P. H. (2002). Management Regim of Fisheries Resource. PT. Pustaka Cidesindo.

Tesfamichael, D., \& Pitcher, T. J. (2006). Multidisciplinary Evaluation of the Sustainability of Red Sea Fisheries Using Rapfish. Fisheries Research, 78, 277-235.

https://doi.org/10.1016/j.fishres.2006.01.005

Kavanagh, P. (2001). Rapid Appraisal of Fisheries (RAPFISH) Project. University of British Columbia, Fisheries Centre. 


\section{Macrothink \\ Environmental Management and Sustainable Development \\ ISSN 2164-7682 \\ 2017, Vol. 6, No. 2}

\section{Copyright Disclaimer}

Copyright for this article is retained by the author(s), with first publication rights granted to the journal.

This is an open-access article distributed under the terms and conditions of the Creative Commons Attribution license (http://creativecommons.org/licenses/by/3.0/). 